\title{
PENGARUH PEMBERDAYAAN IBU DALAM PERAWATAN BAYI MELALUI PENDEKATAN MODELLING
}

\author{
Effect of Mother Empowerment in Infant Care with a \\ Modelling Approach
}

\author{
Ariyanti Saleh ${ }^{1}$, Elly Nurachmah ${ }^{2}$, Veny Hadju ${ }^{3}$, Surayani As'ad ${ }^{4}$, St. Khadijah Hamid $^{3}$ \\ ${ }^{1}$ Program Studi Ilmu Keperawatan, Fakultas Kedokteran, Universitas Hasanuddin, Makassar \\ ${ }^{2}$ Fakultas Keperawatan, Universitas Indonesia, Jakarta \\ ${ }^{3}$ Fakultas Kesehatan Masyarakat, Universitas Hasanuddin, Makassar \\ ${ }^{4}$ Fakultas Kedokteran, Universitas Hasanuddin, Makassar \\ (ariyanti.saleh@gmail.com)
}

\begin{abstract}
ABSTRAK
Ibu merupakan faktor lingkungan yang utama dan dapat berperan terhadap tumbuh kembang bayi melalui pemberian ASI. Pemberian ASI sangat dianjurkan pada bayi sampai anak berusia 2 tahun. Penelitian ini bertujuan mengidentifikasi efektivitas pemberdayaan ibu dalam merawat bayi 0-6 bulan dengan memberikan pendidikan kesehatan dengan pendekatan modeling terhadap pengetahuan dan dukungan keluarga dengan status laktasi bayi. Penelitian ini menggunakan desain quasi eksperiment pre-post control group design. Analisis menggunakan uji wilcoxson dan uji Mann Whitney. Intervensi yang diberikan berupa pemberian pendidikan kesehatan dengan pendekatan modelling tentang manajemen laktasi dan stimulasi tumbuh kembang bayi. Sampel berjumlah 81 orang terdiri atas 41 orang kelompok perlakuan dan 40 orang kelompok kontrol. Hasil penelitian menunjukkan bahwa pengetahuan ibu dari kelompok intervensi dan kontrol masing-masing menunjukkan terdapat perbedaan pengetahuan sebelum dan sesudah intervensi $(\mathrm{p}=0,000 ; \mathrm{p}=0,001)$. Dukungan keluarga dari kelompok intervensi dan kontrol masing-masing menunjukkan terdapat perbedaan pengetahuan sebelum dan sesudah intervensi $(\mathrm{p}=0,000 ; \mathrm{p}=0,009)$. Status laktasi menunjukkan ada perbedaan yang signifikan $(\mathrm{p}=0,001)$ antara kelompok perlakuan dan kelompok kontrol. Kesimpulan dari penelitian bahwa efektivitas pemberdayaan ibu dalam merawat bayi menunjukkan terdapat perbedaan antara pengetahuan, dukungan keluarga dan status laktasi sebelum dan sesudah pemberian pendidikan kesehatan dengan pendekatan modelling.
\end{abstract}

Kata kunci : Pemberdayaan ibu, status laktasi bayi

\section{ABSTRACT}

Mother is the main environmental factor that may contribute to the growth and development of infants through breastfeeding. Breastfeeding is highly recommended for infants and children up to 2 years old. This study aimed to identify the effectiveness of empowerment of mothers in caring for infants 0-6 months old by providing health education with a modeling approach on knowledge, family support, and baby's lactation status. This research used a quasi-experimental pre-post control group design. Analysis was conducted using the wilcoxson test and Mann Whitney test. Interventions conducted were in the form of provision of health education with a modeling approach about lactation management and infant growth stimulation. The sample size was 81 people which consisted of 41 people in the treatment group and 40 people in the control group. Results showed that there were differencesin the knowledge of mothers in the intervention and control groups after intervention with $(p=0,000 ; p=0,001)$. Family support of the intervention and control groups showed differences in knowledge before and after intervention ( $p=0,000 ; p=0,009)$. Lactation status was significantly different $(p=0,001)$ between the treatment and the control groups. It was concluded that the effectiveness of empowerment of mothers in caring for their baby showed a difference in knowledge, family support, and lactation status before and after provision of health education with a modeling approach.

Keywords: Mother empowerment, baby lactation status 


\section{PENDAHULUAN}

Bayi pada awal bulan paling berisiko terhadap berbagai penyakit, Air Susu Ibu (ASI) eksklusif membantu melindungi terhadap diare dan infeksi lainnya. Berdasarkan penelitian di negara maju, ASI dapat menurunkan angka infeksi saluran pernafasan bawah, otitis media (infeksi pada telinga tengah), meningitis bakteri (radang selaput otak), infeksi saluran kemih, diare, dan necrotizing enterocolitis. ${ }^{1}$ Berdasarkan data Survei Demografi dan Kesehatan Indonesia 1997-2007 memperlihatkan terjadinya penurunan prevalensi ASI eksklusif dari 40,2\% pada tahun 1997 menjadi 39,5\% dan $32 \%$ pada tahun 2003 dan $2007 .{ }^{2}$ Berdasarkan data SUSENAS (Survei Sosial Ekonomi Nasional), cakupan pemberian ASI eksklusif di Indonesia berfluktuasi selama 5 tahun terakhir, cakupan pemberian ASI ekskusif pada bayi 0-6 bulan turun dari $62,2 \%$ tahun 2007 menjadi $56,2 \%$ pada tahun 2008, tetapi meningkat lagi pada tahun 2009 menjadi $61,2 \%$. Angka ini meningkat menjadi $61,3 \%$ tahun 2010 dan kembali turun menjadi $61,1 \%$ pada tahun 2011. ${ }^{3}$ Salah satu sasaran program dalam menuju Indonesia sehat tahun 2010 adalah sekurang-kurangnya $80 \%$ ibu menyusui memberikan ASI eksklusif kepada bayinya. ${ }^{4}$ Berdasarkan Riset Kesehatan Dasar (Riskesdas) 2010 menyebutkan, hanya $15,3 \%$ bayi umur kurang dari 6 bulan yang mendapat ASI eksklusif. ${ }^{5}$

Banyak faktor yang berhubungan dengan praktik menyusui eksklusif, diataranya adalah kurangnya pengetahuan dan kesadaran ibu akan pentingnya pemberian ASI secara eksklusif, pelayanan kesehatan dan petugas kesehatan yang belum sepenuhnya mendukung program Peningkatan Penggunaan Air Susu Ibu (PP-ASI), gencarnya promosi susu formula, rasa percaya diri ibu yang masih kurang, tingkat pendidikan ibu, dukungan suami dan rendahnya pengetahuan ibu tentang manfaat ASI bagi bayi dan ibu. Dukungan keluarga, terutama suami dapat menentukan keberhasilan atau kegagalan menyusui, sebab dukungan suami akan menimbulkan rasa nyaman pada ibu sehingga akan memengaruhi produksi ASI serta meningkatkan semangat dan rasa nyaman dalam menyusui. ${ }^{6,7}$

Rendahnya pengetahuan berkaitan dengan informasi yang keliru tentang pentingnya ASI, membentuk para ibu menyusui menjadi faktor ke- gagalan pemberian ASI eksklusif. Dari pernyataan tersebut, sekelompok yang peduli ASI secara konsisten terus menerus menyuarakan pentingnya pemberian ASI di awal kehidupan bayi. Mereka yakin bahwa rendahnya keberhasilan pemberian ASI eksklusif dikarenakan kurangnya pengetahuan dari orang tua bayi dan keluarga. Kurangnya dukungan keluarga untuk menyusui seperti yang dialami oleh ibu-ibu di pedesaan. Di daerah pedesaan rata-rata ibu menyusui bayi mereka, tetapi pengaruh kebiasaan yang kurang menunjang pemanfaatan ASI secara optimal, seperti pemberian makanan tambahan, pemberian makanan atau minuman untuk penggantian ASI karena ASI keluar pada hari-hari pertama setelah kelahiran. ${ }^{7}$

Peran seorang ibu sangat penting, terutama sebagai agen kesehatan bagi anak dan keluarga dalam upaya memenuhi kebutuhan asah, asuh, asih pada bayi. Oleh karena itu, setiap ibu yang memiliki bayi memerlukan pengetahuan, sikap dan keterampilan yang benar serta memiliki kepercayaan diri yang tinggi tentang hal tersebut. Perawat sebagai salah satu profesi kesehatan memiliki tanggung jawab untuk mempromosikan kesehatan keluarga dan anak, menyediakan layanan pada klien yang meliputi dukungan, pendidikan kesehatan dan pelayanan keperawatan yang dapat berkontribusi dalam meningkatkan pengetahuan, sikap dan keterampilan ibu dalam merawat bayinya. ${ }^{8}$

Teori keperawatan Maternal Role Attainment (MRA) dapat digunakan sebagai kerangka konseptual penelitian dalam meningkatkan peran ibu dan percaya diri ibu dalam merawat bayi. ${ }^{9}$ Berdasarkan hal tersebut, maka penelitian ini menjadikan teori keperawatan sebagai dasar pemikiran. Teori keperawatan MRA merupakan salah satu dari teori middle range yang dikembangkan oleh Ramona T. Mercer, yang berfokus pada ibu dalam mengembangkan perannya sebagai seorang ibu agar lebih percaya diri dalam melakukan perawatan anak-anaknya, melalui upaya pemberian pendidikan kesehatan (penkes) oleh perawat. ${ }^{8,10}$ Beberapa asumsi yang mendasari teori ini adalah karakteristik ibu, percaya diri ibu, status kesehatan bayi dan hasil akhir berupa status tumbuh kembang bayi. ${ }^{10}$ Pengamatan di lapangan juga menunjukkan masih banyak ditemukan praktik pengasuhan bayi dan pemberian ASI yang kurang optimal. Untuk itu diperlukan penkes yang dapat merubah 
perilaku ibu melalui pengetahuan, sikap, kemampuan, dan kepercayaan diri yang tinggi dalam merawat bayi khususnya dalam pemberian ASI kepada bayi. Penkes dengan pendekatan modelling adalah pendidikan kesehatan kepada ibu yang menggunakan peniruan (modelling) yang merupakan komponen penting dalam pembelajaran melalui obsevasi, yang dilakukan oleh peneliti dalam mempelajari tumbuh kembang melalui pemberian ASI, menurut Bandura pembelajaran observasi jauh lebih efisien dibanding belajar melalui pengalaman langsung karena dalam pembelajaran modelling ini seseorang akan melibatkan proses kognitif aktif yang meliputi empat komponen yaitu: atensi, retensi, reproduksi dan motivasi. proses pelaksanaan penkes modelling. ${ }^{11}$ Beberapa studi penelitian telah menunjukkan bahwa melalui pendekatan modelling berkorelasi yang signifikan terhadap motivasi dalam perbaikan status kesehatan dibandingkan dengan kontrol. ${ }^{12-14}$

Penelitian ini bertujuan mengidentifikasi efektivitas pemberdayaan ibu dalam merawat bayi 0-6 bulan dengan memberikan pendidikan kesehatan dengan pendekatan modelling terhadap pengetahuan dan dukungan keluarga dengan status laktasi bayi. Pendidikan kesehatan pada penelitian ini adalah berdasar pada teori belajar sosial oleh Bandura dengan konsep intinya adalah pendekatan modelling yang mengedepankan pelaksanaan praktik pada pelaksanaan penkesnya.

\section{BAHAN DAN METODE}

Penelitian ini telah dilaksanakan di Kabupaten Maros. Keseluruhan sampel berjumlah 81 orang ibu terdiri dari 41 orang kelompok intervensi dan 40 orang kelompok kontrol sesuai dengan kriteria penelitian. Metode yang digunakan dalam pendidikan kesehatan (penkes) adalah demonstrasi, redemonstrasi dan simulasi, sedangkan alat bantu penkes yang digunakan adalah leaflet, lembar balik dan pantom. Metode dalam penelitian ini adalah quasi eksperiment pre-post with control group design. Upaya pemberdayaan ibu adalah dengan memberikan pendidikan kesehatan (penkes). Perlakuannya (intervensi) berupa pemberian penkes dengan pendekatan modelling. Penkes yang digunakan adalah penkes dengan pendekatan modelling yang memfokuskan praktik dalam aktifitasnya. Penkes dilakukan sebanyak tiga kali seti- ap pemberian penkes dilakukan selama 45 menit. Tahap penkes yaitu penkes I dengan menggunakan modul tentang manajemen laktasi (pemberian ASI) yang diberikan pada pada akhir trimester III kehamilan. Penkes II dengan menggunakan modul tentang stimulasi tumbuh kembang 1 (bayi 0-3 bulan) yang diberikan pada minggu pertama post partum dan penkes III dengan menggunakan modul tentang stimulasi tumbuh kembang 2 (bayi 3-6 bulan) yang diberikan ketika usia bayi 3 bulan. Proses belajar modelling ini memiliki empat fase, yaitu atensi, retensi, reproduksi dan motivasi, yang sebagian besar fase-fase tersebut merupakan proses internal dari subjek belajar dalam menjalani pembelajaran sosial. Lembar balik, leaflet, pantom boneka bayi merupakan alat bantu dalam pelaksanaan penkes ini. Penkes diberikan oleh petugas yang dilatih khusus.

Instrumen penelitian yang digunakan dalam penelitian ini adalah kuesioner dan lembar observasi. Variabel yang diukur sebelum dan setelah intervensi adalah pengetahuan, dukungan keluarga dan status laktasi. Analisis data yang dilakukan secara univariat dan bivariat untuk melihat gambaran umum setiap variabel, distribusi, dan frekuensinya seperti (jenis kelamin dan usia) dan melihat hubungan asupan zat gizi dengan status gizi. Hasil yang diperoleh diuji menggunakan uji chi square, uji wilcoxon dan uji mann whitney. Penyajian data dengan menggunakan tabel dan dijelaskan secara deskriptif.

\section{HASIL}

Hasil uji homogenitas responden berdasarkan usia ibu, usia suami, pekerjaan suami dan pendapatan keluarga. Hasil penelitian menunjukkan bahwa antara kelompok perlakuan dan kelompok kontrol telah memiliki kesetaraan/homogenitas. Hasil uji homogenitas antara kelompok perlakuan dan kelompok kontrol pada rerata usia ibu didapat nilai $\mathrm{p}=0,78$, rerata usia suami didapat nilai $\mathrm{p}=0,49$, pekerjaan suami didapat nilai $\mathrm{p}=0,26$ dan pendapatan keluargadidapat nilai $\mathrm{p}=0,19$ (Tabel 1).

Terdapat perbedaan pengetahuan antara kelompok perlakuan dan kelompok kontrol hal ini juga didukung oleh hasil analisis terhadap perubahan pengetahuan di antara kedua kelompok. Bila dilakukan kategorisasi perubahan skor pengeta- 
huan, maka setelah intervensi pendidikan kesehatan dengan pendekatan modelling tentang manajemen laktasi dan tumbuh kembang bayi, ibu pada kelompok perlakuan yang mengalami peningkatan pengetahuan sebanyak 75,6\%. Pada kelompok kontrol, meskipun tidak diberikan pendidikan kesehatan secara langsung oleh petugas dari tim peneliti, tetapi ibu juga mengalami peningkatan pengetahuan sebanyak $75 \%$. Berdasarkan uji chi square didapat nilai $\mathrm{p}=0,949$, ini artinya tidak terdapat perbedaan pada perubahan pengetahuan ibu pada kelompok perlakuan dan kelompok kontrol (Tabel 2). mann whitney diperoleh nilai $\mathrm{p}=0,004$, artinya ada perbedaan dukungan keluarga antara kelompok perlakuan dan kelompok kontrol setelah dilakukan intervensi, hasil ini menunjukkan bahwa hipotesis mayor keempat diterima yaitu ada perbedaan dukungan keluarga dari ibu yang diberikan pendidikan kesehatan dengan kelompok ibu tanpa diberikan pendidikan kesehatan (Tabel 3).

Variabel status laktasi bayi menunjukkan bahwa terdapat perbedaan yang signifikan $(\mathrm{p}=0,001)$ antara kelompok perlakuan dan kelompok kontrol setelah diberikan pendidikan kesehatan dengan pendekatan modelling tentang ma-

Tabel 1. Karakteristik Responden

\begin{tabular}{lcc}
\hline \multicolumn{1}{c}{ Variabel } & \multicolumn{2}{c}{ Kelompok } \\
\cline { 2 - 3 } & Perlakuan $(\mathbf{n = 4 1 )}$ & Kontrol $(\mathbf{n}=\mathbf{4 0}) \mathbf{p}$ \\
\hline Usia ibu rata - rata (tahun) & $25,15 \pm 4,59$ & $25,1 \pm 5,460,78^{*}$ \\
Usia suami rata - rata (tahun) & $28,3 \pm 5.15$ & $29,6 \pm 5,960,49^{*}$ \\
Pendidikan ibu & & \\
$\quad$ Rendah & $36(87,8)$ & $26(65,0) 0,005^{* *}$ \\
$\quad$ Tinggi & $5(12,2)$ & $14(35,0)$ \\
Pendidikan Suami & & $17(42,5) 0,01^{* *}$ \\
$\quad$ Rendah & $30(73,2)$ & $23(57,5)$ \\
$\quad$ Tinggi & $11(26,8)$ & $5(12,2) 0.26^{* *}$ \\
Pekerjaan Suami & & $35(87,5)$ \\
$\quad$ PNS/TNI/POLRI & $2(4,9)$ & $26(65,0) 0,19^{* *}$ \\
$\quad$ Wiraswasta & $39(95,1)$ & $14(35,0)$ \\
Pendapatan Keluarga & & $27(67,5) 0.01^{* *}$ \\
$\quad \leq 1$ juta & $32(78.0)$ & $13(32,5)$ \\
$\quad$ 1 juta & $9(22.0)$ & \\
$\quad$ Jumlah Anggota keluarga & &
\end{tabular}

Keterangan: * Uji t tidak berpasangan, ${ }^{* *}$ Uji chi-square

Sumber : Data Primer, 2009

Variabel dukungan keluarga menunjukkan bahwa pada kelompok perlakuan nilai median sebelum intervensi 43,70, setelah intervensi 48,01 dan nilai median perubahan 40,00 , dengan menggunakan uji wilcoxon didapatkan nilai $\mathrm{p}=0,000$. Hal ini berarti ada peningkatan dukungan keluarga pada kelompok perlakuan. Pada kelompok kontrol nilai median sebelum intervensi 38,24 , setelah intervensi 33,8 dan perubahan 41,00 , berdasarkan uji wilcoxon didapatkan nilai $\mathrm{p}=0,009$, artinya terdapat juga peningkatan dukungan keluarga pada kelompok kontrol. Hasil analisis menggunakan uji najemen laktasi. Hasil ini menunjukkan bahwa hipotesis minor keenam diterima yaitu terdapat perbedaan status laktasi bayi dari ibu yang diberikan pendidikan kesehatan dengan kelompok ibu tanpa diberikan pendidikan kesehatan (Tabel 4). Hubungan perubahan pengetahuan ibu dengan status laktasi bayi menunjukkan bahwa tidak ada hubungan antara perubahan pengetahuan dengan status laktasi bayi. Hubungan perubahan pengetahuan ibu dengan status laktasi yaitu pada kelompok perlakuan $(\mathrm{p}=1,00)$ dan pada kelompok kontrol $(\mathrm{p}=0,25)($ Tabel 5). 
Tabel 2. Perubahan Pengetahuan Ibu Antara Kelompok Perlakuan dengan Kelompok Kontrol

\begin{tabular}{|c|c|c|c|c|c|c|c|}
\hline \multirow{3}{*}{ Kelompok } & \multicolumn{4}{|c|}{ Pengetahuan Ibu } & \multirow{2}{*}{\multicolumn{2}{|c|}{ Total }} & \multirow{3}{*}{$\mathbf{p}$} \\
\hline & \multicolumn{2}{|c|}{ Meningkat } & \multicolumn{2}{|c|}{ Tetap/Menurun } & & & \\
\hline & $\mathbf{n}$ & $\%$ & n & $\%$ & $\mathbf{n}$ & $\%$ & \\
\hline Perlakuan & 31 & 75,6 & 10 & 24,4 & 41 & 100 & \multirow{2}{*}{0,949} \\
\hline Kontrol & 30 & 75,0 & 10 & 25,0 & 40 & 100 & \\
\hline
\end{tabular}

Sumber : Data Primer, 2009

Tabel 3. Perbedaan Dukungan Keluarga antara Kelompok Perlakuan dengan Kelompok Kontrol

\begin{tabular}{lcccc}
\hline \multirow{2}{*}{ Kelompok } & \multicolumn{3}{c}{ Dukungan Keluarga } & \multirow{2}{*}{$\mathbf{p}^{*}$} \\
\cline { 2 - 3 } & Sebelum & Setelah & Perubahan & \\
\hline Perlakuan $(\mathrm{n}=4)$ & 43,70 & 48,01 & 40,00 & 0,000 \\
Kontrol $(\mathrm{n}=40)$ & 38,24 & 33,81 & 41,00 & 0,009 \\
$\mathrm{p}^{* *}$ & 0,283 & 0,004 & 0,317 & \\
\hline
\end{tabular}

Keterangan: *Uji Wilcoxon**Uji Mann Whitney

Sumber : Data Primer, 2009

\section{PEMBAHASAN}

Hasil penelitian uji homogenitas berdasarkan karaktersitik responden menunjukkan tidak ada perbedaan antara variabel usia ibu, usia suami, pekerjaan suami dan pendapatan keluarga. Uji ini membantu menunjukkan sebelum dilakukan perlakuan tidak ada perbedaan variabel yang akan menjadi variabel pengganggu. Menurut penelitian Setiawati menunjukkan bahwa faktor umur ibu terdapat hubungan terhadap praktik pemberian ASI eksklusif yaitu dengan nilai $\mathrm{p}=0,039 .{ }^{15} \mathrm{Hal}$ ini tidak sejalan dengan penelitian Anggrita di Medan menunjukkan bahwa tidak terdapat hubungan bermakna antara umur ibu terhadap pemberian ASI eksklusif. ${ }^{16} \mathrm{Hal}$ ini juga tidak sejalan dengan penelitian Isniani di Makassar Tengah yang menunjukkan bahwa terdapat hubungan tidak signifikan antara umur ibu dengan pemberian ASI eksklusif dengan nilai $p=0,317 .{ }^{17}$ Variabel pendapat keluarga menurut dengan pemberian ASI eksklusif dari hasil penelitian Anggrita menunjukkan tidak ada hubungan antara pendapatan. ${ }^{18}$

Air Susu Ibu (ASI) merupakan makanan yang terbaik bagi bayi karena mengandung semua zat gizi dalam jumlah dan komposisi yang ideal yang dibutuhkan oleh bayi untuk tumbuh dan berkembang secara optimal, terutama pada umur 0 sampai 6 bulan. Pemberian ASI eksklusif kepada bayi umur 0-6 bulan sangat dianjurkan dan memberikan makanan pendamping ASI secara benar setelah itu sampai bayi/anak berumur dua tahun. ${ }^{6}$ Banyak faktor yang berhubungan dengan praktik menyusui eksklusif, diataranya adalah kurangnya pengetahuan dan kesadaran ibu akan pentingnya pemberian ASI secara eksklusif. Salah satu hambatan praktik pemberian ASI eksklusif yang berasal dari faktor ibu (predisposisi) adalah pengetahuan masih kurang tentang manfaat ASI eksklusif dan teknik menyusui, sehingga motivasi untuk menyusui secara eksklusif lemah. Orang yang memengaruhi praktik pemberian ASI eksklusif adalah suami, nenek, saudara dan teman selain itu komitmen yang kurang dan padatnya aktivitas tenaga kesehatan di puskesmas sehingga fokus untuk memberikan konseling laktasi kepada ibu hamil dan menyusui berkurang. ${ }^{19}$

Hasil penelitian ini melalui upaya pemberdayaan ibu adalah dengan memberikan pendidikan kesehatan (penkes) menunjukkan tidak terdapat perbedaan pengetahuan ibu pada kelompok perlakuan dan kelompok kontrol, tetapi terdapat perbedaan pengetahuan ibu setelah diberikan intervensi. Hal ini didukung oleh penelitian Ambarwati bahwa berdasarkan hasil uji statistik menunjukkan ada perbedaan praktik pemberian ASI eksklusif antara kelompok perlakuan dan kontrol $(p=0,0001)$, perbedaan ini disebabkan oleh ada peningkatan pengetahuan dan perubahan sikap pada ibu yang mendapatkan konseling laktasi yang intensif dibanding dengan ibu yang tidak mendapat konseling laktasi yang intensif. ${ }^{20}$ 
Penkes dalam penelitian ini dilaksanakan sebanyak tiga kali sehingga dapat mempertahankan pengetahuan ibu. Menurut Notoadmodjo bahwa intensitas konseling merupakan salah satu yang memengaruhi peningkatan pengetahuan ibu, sehingga semakin sering terjadi kontak antara ibu dan konselor maka semakin sering ibu mendapatkan informasi yang secara tidak langsung meningkatkan pengetahuan ibu. Manfaat lain dari intensitas konseling yang sering adalah adanya pengulangan informasi yang menjadi faktor pendukung dalam pemahaman ibu terhadap informasi tersebut. Informasi atau pengetahuan yang sering dan berulang-ulang dapat meningkatkan retensi penge-
ASI adalah suatu emulsi lemak dalam larutan protein, laktose, dan garam organik yang disekresi oleh kedua belah kelenjar payudara ibu, sebagai makanan utama bagi bayi. Komposisi ASI tidak sama dari waktu ke waktu, hal ini berdasarkan stadium laktasi. Manfaat pemberian ASI untuk bayi antara lain ASI mengandung banyak zat gizi diantaranya lemak, karbohidrat, protein, garam dan mineral, serta vitamin, bayi yang mendapat ASI lebih jarang menderita penyakit, karena adanya zat protektif dalam ASI. Zat protektif tersebut antara lain lactobasilus bifidus, laktoferin, lisozim, dan antibodi. Bagi yang mendapatkan ASI mempunyai kenaikan berat badan yang baik setelah

Tabel 4. Kategori Status Laktasi antara Kelompok Perlakuan dengan Kelompok Kontrol

\begin{tabular}{lcccccccc}
\hline \multirow{2}{*}{ Kelompok } & \multicolumn{4}{c}{ Status Laktasi } & \multicolumn{2}{c}{ Total } & \multirow{2}{*}{ p } \\
\cline { 2 - 7 } & \multicolumn{3}{c}{ Ekslusif } & \multicolumn{2}{c}{ Tidak Ekslusif } & & & \\
\cline { 2 - 7 } & $\mathbf{n}$ & $\mathbf{\%}$ & $\mathbf{n}$ & $\mathbf{\%}$ & $\mathbf{n}$ & $\mathbf{\%}$ & \\
\hline Perlakuan & 12 & 29,3 & 29 & 70,7 & 41 & 100 & \multirow{2}{*}{0,001} \\
Kontrol & 1 & 2,5 & 39 & 97,5 & 40 & 100 & \\
\hline
\end{tabular}

Sumber : Data Primer, 2009

Tabel 5. Hubungan Perubahan Pengetahuan Ibu dengan Status Laktasi Bayi

\begin{tabular}{|c|c|c|c|c|}
\hline \multirow[b]{2}{*}{ Kelompok } & \multirow[b]{2}{*}{ Perubahan Pengetahuan Ibu } & \multicolumn{2}{|c|}{ Status Laktasi } & \multirow[b]{2}{*}{$\mathbf{p}$} \\
\hline & & $\begin{array}{c}\text { Tidak Ekslusif } \\
\text { n(\%) }\end{array}$ & $\begin{array}{c}\text { Ekslusif } \\
\text { n(\%) }\end{array}$ & \\
\hline Perlakuan & $\begin{array}{l}\text { Meningkat }(\mathrm{n}=31) \\
\text { Tetap / menurun }(\mathrm{n}=10)\end{array}$ & $\begin{array}{c}22(70,9) \\
7(70)\end{array}$ & $\begin{array}{l}9(29,1) \\
3(30)\end{array}$ & 1,00 \\
\hline Kontrol & $\begin{array}{l}\text { Meningkat }(\mathrm{n}=30) \\
\text { Tetap/menurun }(\mathrm{n}=10)\end{array}$ & $\begin{array}{l}30(100) \\
9(90)\end{array}$ & $\begin{array}{c}0(0) \\
1(10)\end{array}$ & 0,25 \\
\hline
\end{tabular}

Sumber : Data Primer, 2009

tahuan seseorang. ${ }^{21}$ Waktu yang digunakan untuk konseling disesuaikan dengan waktu yang diinginkan oleh ibu, hal ini akan berdampak terhadap kesiapan ibu dalam mengikuti konseling sehingga membuat suasana proses belajar lebih kondusif dan berdampak terhadap keberhasilan dalam penerimaan informasi tersebut. ${ }^{20}$

Berdasarkan penelitian Rachmania menunjukkan terdapat hubungan pengetahuan dengan pemberian ASI dengan nilai $\mathrm{p}=0,008 .{ }^{22}$ Hasil penelitian menunjukkan bahwa terdapat hubungan yang bermakna antara tingkat pengetahuan ibu tentang ASI dengan pemberian ASI eksklusif $(\mathrm{p}=0,001){ }^{23}$ lahir, pertumbuhan satelah periode perinatal baik, dan mengurangi kemungkinan obesitas, waktu menyusu kulit bayi akan menempel pada kulit ibu. Kontak kulit yang dini akan sangat besar pengaruhnya pada perkembangan bayi kelak. ${ }^{7}$

Hasil dari dukungan keluarga sebelum intervensi yaitu tidak terdapat perbedaan pemberian dukungan keluarga antara kelompok intervensi dan kelompok kontrol. Setelah intervensi terdapat perbedaan pemberian dukungan keluarga antara kelompok intervensi dan kelompok kontrol. Hal ini didukung oleh penelitian Rahmawati bahwa terdapat hubungan antara dukungan keluarga dengan pemberian ASI eksklusif $(p=0,000<\alpha=0,005)$ 
di wilayah kerja Puskesmas Bonto Cani Kabupaten Bone serta berkorelasi negatif artinya bahwa semakin tinggi dukungan keluarga maka semakin rendah pula pemberian ASI eksklusif yang dilakukan. ${ }^{24}$ Menurut Watson dalam Friedman bahwa salah satu bentuk dukungan keluarga berupa pemberian bantuan dalam bentuk materi seperti pinjaman uang, bantuan fisik berupa alat-alat atau lainnya yang mendukung dan membantu menyelesaikan masalah. Dalam mengatasi ketegangan kehadiran keluarga sangat penting untuk mendorong ibu dalam meningkatkan kepercayaan diri dan menstabilkan emosinya, serta memberikan motivasi yang besar terhadap ibu yang menyusui. Dukungan keluarga mempunyai hubungan dengan suksesnya pemberian ASI eksklusif kepada bayi. Dukungan keluarga adalah dukungan untuk memotivasi ibu memberikan ASI saja kepada bayinya sampai usia 6 bulan, memberikan dukungan psikologis kepada ibu dan mempersiapkan nutrisi yang seimbang kepada ibu..$^{24,25}$

Penelitian Anggorowati menunjukkan ada hubungan antara dukungan keluarga dengan pemberian ASI dengan nilai $\mathrm{p}=0,003$. Dukungan keluarga mempunyai hubungan dengan suksesnya pemberian ASI eksklusif pada bayi, hal ini didukung oleh pengetahuan keluarga tentang pemberian ASI yang baik. Ibu menyusui perlu meningkatkan rasa percaya diri dan motivasi dalam memberikan ASI, menambah pengetahuan tentang pemberian ASI yang benar melalui penyuluhan di tempat pelayanan kesehatan. ${ }^{26} \mathrm{Hal}$ ini sependapat dengan Sudiharto menyatakan bahwa dukungan keluarga mempunyai hubungan dengan suksesnya pemberian ASI eksklusif kepada bayi. Dukungan keluarga adalah dukungan untuk memotivasi ibu memberikan ASI saja kepada bayinya sampai usia 6 bulan, memberikan dukungan psikologis kepada ibu dan mempersiapkan nutrisi yang seimbang kepada ibu. ${ }^{27}$

Hasil penelitian menunjukkan bahwa ada pengaruh pemberian pendidikan kesehatan dengan pendekatan modelling tentang manajemen laktasi terdapat perbedaan status laktasi antara kelompok kontrol dan kelompok intervansi, tetapi tidak ada hubungan antara perubahan pengetahuan dengan status laktasi bayi. Hal ini bertentangan dengan hasil penelitian Merdhika bahwa terdapat pengaruh penyuluhan ASI eksklusif terhadap pengetahuan ibu menyusui. Pengetahuan ibu sesudah diberikan penyuluhan mengalami peningkatan terhadap pengetahuan yang sangat signifikan terdapat pada pengetahuan tentang manfaat utama ASI eksklusif bagi bayi membuktikan bahwa terdapat pengaruh penyuluhan kesehatan tentang ASI eksklusif terhadap pengetahuan dan terdapat beda rerata antara sebelum dan sesudah pemberian penyuluhan kesehatan dan sikap ibu menyusui dalam pemberian ASI eksklusif. ${ }^{28}$

Pengetahuan ibu yang kurang tentang ASI eksklusif inilah yang terutama menyebabkan gagalnya pemberian ASI eksklusif. Padahal pengetahuan merupakan dasar utama manusia untuk melakukan sesuatu. Informasi yang harus disampaikan mengenai ASI eksklusif, yaitu keuntungan dan keunggulan ASI, makanan ibu hamil dan menyusui serta persiapan menyusui dalam waktu lama harus disampaikan pada ibu saat dalam masa kehamilan. ${ }^{29}$ Hasil penelitian Imdad et al. menunjukkan bahwa pemberian konseling prenatal memiliki dampak terhadap pemberian ASI sampai 4-6 minggu, sedangkan konseling yang diberikan pada saat pranatal dan postnatal berpengaruh terhadap pemberian ASI eksklusif sampai dengan 6 bulan..$^{30}$ Pendapat ini bertentangan dengan Sartono, yaitu tiga variabel yang diteliti (pengetahun ibu, pendidikan ibu dan dukungan suami) secara terpisah maupun bersamaan tidak berhubungan dengan praktik pemberian ASI eksklusif. Praktik pemberian ASI eksklusif lebih ditentukan oleh keinginan pribadi ibu dan keberhasilan manajemen laktasi pada saat pertolongan persalinan di institusi pelayanan kesehatan, yang sangat diwarnai oleh komitmen petugas kesehatan (penolong persalinan) terhadap program peningkatan ASI eksklusif. ${ }^{6}$ Intervensi telah dilaksanakan dengan benar sesuai standar. Melalui kontrol kualitas melalui standarisasi petugas pemberi penkes, standarisasi modul penkes, standarisasi instrumen, kontrol lapangan dan kontrol manejemen data melalui data entry. Kelemahan dari penelitian ini hanya menggunakan teknik sampling consecutive karena sampel yang memenuhi kriteria penelitian jumlahnya sangat terbatas. Namun demikian, jumlah sampel tersebut tetap dapat dikatakan memenuhi syarat untuk jumlah sampel besar $(n>20)$ pada penelitian yang menggunakan uji Mann Whitney. ${ }^{31}$ Uji validitas pada instrumen pengetahuan dan 
sikap, hanya dilakukan uji face validity. Untuk data berskala ordinal atau nominal dapat digunakan uji face validity. ${ }^{32,33}$

\section{KESIMPULAN DAN SARAN}

Penelitian ini menyimpulkan bahwa terdapat perbedaan pengetahuan ibu $(p=0,000)$, dukungan keluarga $(p=0,004)$ dan status laktasi bayi $(\mathrm{p}=0,001)$ antara kelompok perlakuan dan kelompok kontrol setelah diberikan pendidikan kesehatan dengan pendekatan modelling tentang manajemen laktasi. Hubungan perubahan pengetahuan ibu dengan status laktasi bayi menunjukkan bahwa tidak ada hubungan antara perubahan pengetahuan dengan status laktasi bayi. Hubungan perubahan pengetahuan ibu dengan status laktasi yaitu pada kelompok perlakuan $(p=1,00)$ dan pada kelompok kontrol $(p=0,25)$ bahwa efektifitas pemberdayaan ibu dalam merawat bayi menunjukkan terdapat perbedaan antara pengetahuan, dukungan keluarga dan status laktasi sebelum dan sesudah pemberian pendidikan kesehatan dengan pendekatan modelling. Saran kepada pemerintah agar menyediakan pendidikan kesehatan untuk petugas kesehatan, kader, keluarga ibu hamil serta ibu hamil tersebut setiap bulan pada jadwal posyandu agar dapat mensosialisasikan pentingnya pemberian ASI eksklusif sejak bayi lahir sampai berumur 6 bulan dan tetap memberikan ASI sampai berumur dua tahun.

\section{DAFTAR PUSTAKA}

1. Proverawati A, Asfuah S. Gizi untuk Kebidanan. Yogyakarta: Nuha Medika; 2009.

2. Fikawati S, Syafiq A. Penyebab Keberhasilan dan Kegagalan Praktik Pemberian ASI Eksklusif. Kesmas: Jurnal Kesehatan Masyarakat Nasional. 2009;4(3):120-131.

3. Sukrastawan I, Seri Ani L. Proporsi Pemberian ASI Eksklusif pada Bayi Usia 6 sampai 12 Bulan di Wilayah Kerja Puskesmas Gianyar II Tahun 2013. E-Jurnal Medika Udayana. 2015;4(3).

4. Nuzulia F. Hubungan antara Dukungan Keluarga dengan Pemberian ASI Eksklusif pada Bayi di Desa Bebengan Kecamatan Boja Kabupaten Kendal. Jurnal Keperawatan Maternitas. $2013 ; 1(1)$.

5. Riskesdas. Laporan Hasil Riset Kesehatan
Dasar (Riskesdas) 2010. Jakarta: Badan Litbangkes, Depkes RI; 2010.

6. Sartono A, Utaminingrum H. Hubungan Pengetahuan Ibu, Pendidikan Ibu dan Dukungan Suami dengan Praktek Pemberian ASI Eksklusif di Kelurahan Muktiharjo Kidul Kecamatan Telogosari Kota Semarang. Jurnal Gizi Universitas Muhammadiyah Semarang. 2012;1(1):1-9.

7. Setiyowati W, Khilmiana R. Hubungan Pengetahuan tentang ASI Eksklusif pada Ibu Bekerja dengan Pemberian ASI Eksklusif. Jurnal Kebidanan. 2010;2(1):1-8.

8. Mercer Rt, Walker Lo. A Review of Nursing Interventions to Foster Becoming A Mother. Journal of Obstetric, Gynecologic, \& Neonatal Nursing. 2006;35(5):568-582.

9. Russell K. Maternal Confidence of First-Time Mothers During Their Child's Infancy. Georgia: School of Nursing, Georgia State University; 2006.

10. Silver Rm, Landon MB, Rouse DJ,et al. Maternal Morbidity Associated with Multiple Repeat Cesarean Deliveries. Obstetrics \& Gynecology. 2006;107(6):1226-1232.

11. Hall C, Lindzey G, Loehlin JC, Manosevitz M, Locke VO. Introduction to Theories of Personality: John Wiley\&Sons; 1985.

12. Brown R, Ogden J. Children's Eating Attitudes and Behaviour: A Study of the Modelling And Control Theories of Parental Influence. Health Education Research. 2004;19(3):261-271.

13. Duncan C, Jones K, Moon G. Health-Related Behaviour In Context: A Multilevel Modelling Approach. Social Science \& Medicine. 1996;42(6):817-830.

14. Hardeman W, Sutton S, Griffin S, et al. A Causal Modelling Approach to the Development of Theory-Based Behaviour Change Programmes For Trial Evaluation. Health Education Research. 2005;20(6):676-687.

15. Setiawati. Faktor-Faktor yang Berhubungan dengan Pemberian ASI Eksklusif pada Anak Umur 6 - 24 Bulan di Kecamatan Wado Kabupaten Sumedang Tahun 2007 [Skripsi]. Depok: Fakultas Kesehatan Masyarakat, Universitas Indonesia; 2007.

16. Anggrita. Hubungan Karakteristik Ibu Menyusui terhadap Pemberian ASI Eksklusif di 
Wilayah Kerja Puskesmas Medan Amplas Tahun 2009 [Skripsi]. Medan: Fakultas Kedokteran, Universitas Sumatera Utara; 2009.

17. Agam I, Syam A. Faktor-Faktor yang Mempengaruhi Pemberian ASI Eksklusif di Kelurahan Tamamaung Kecamatan Panakkukang Kota Makassar [Skripsi]. Makassar: Program Studi Ilmu Gizi. Fakultas Kesehatan Masyarakat, Unhas; 2013.

18. Anggrita K. Hubungan Karakteristik Ibu Menyusui terhadap Pemberian ASI Eksklusif di Wilayah Kerja Puskesmas Medan Amplas Tahun 2009 [Skripsi]. Medan: Fakultas Kedokteran, Universitas Sumatra Utara; 2010.

19. Noer E. Beberapa Faktor Determinan dalam Praktik Inisiasi Menyusu Dini dan Pemberian ASI Eksklusif Selama 4 Bulan [Tesis]. Semarang : Gizi Masyarakat, Universitas Diponegoro; 2009.

20. Ambarwati R, Muis SF, Susanti P. Pengaruh Konseling Laktasi Intensif Terhadap Pemberian Air Susu Ibu (ASI) Eksklusif Sampai 3 Bulan. Jurnal Gizi Indonesia. 2013;2(1):15-23.

21. Notoatmodjo S. Pendidikan Kesehatan dan Ilmu Perilaku. Jakarta: PT. Rineka Cipta; 2003.

22. Rachmaniah N. Hubungan Tingkat Pengetahuan Ibu tentang ASI dengan Tindakan ASI Eksklusif [Skripsi]. Surakarta: Fakultas Kedokteran, Universitas Muhammadiyah Surakarta; 2014.

23. Lestari D, Zuraida R, Larasati T. Hubungan Tingkat Pengetahuan Ibu tentang Air Susu Ibu dan Pekerjaan Ibu dengan Pemberian ASI Eksklusif di Kelurahan Fajar Bulan. Majority. 2013;2(4).

24. Rahmawati A, Bahar B, Salam A. Hubungan antara Karakteristik Ibu, Peran Petugas Kesehatan dan Dukungan Keluarga dengan Pemberian ASI Eksklusif di Wilayah Kerja Puskesmas Bonto Cani Kabupaten Bone [Skripsi]. Makassar: Program Studi Ilmu Gizi. Fakultas Kesehatan Masyarakat, Unhas; 2014.

25. Friedman Mm. Keperawatan Keluarga Teori dan Praktik. Jakarta: EGC. 1998;177.

26. Anggorowati, Nuzulia F. Hubungan antara Dukungan Keluarga dengan Pemberian ASI Eksklusif pada Bayi di Desa Bebengan, Kecamatan Boja Kabupaten Kendal. Jurnal Keperawatan Maternitas. 2013;1(1):1-8.

27. Sudiharto. Asuhan Keperawatan Keluarga dengan Pendekatan Keperawatan Transkultural. Jakarta: EGC; 2007.

28. Merdhika War, Mardji M, Devi M. Pengaruh Penyuluhan Asi Eksklusif terhadap Pengetahuan Ibu tentang ASI Eksklusif dan Sikap Ibu Menyusui di Kecamatan Kanigoro Kabupaten Blitar. Teknologi dan Kejuruan. 2014;37(1).

29. Astuti I. Determinan Pemberian ASI Eksklusif pada Ibu Menyusui. Jurnal Health Quality. 2013;4(1):1-76.

30. Imdad A, Yakoob MY, Bhutta ZA. Effect of Breastfeeding Promotion Interventions on Breastfeeding Rates, with Special Focus on Developing Countries. BMC Public Health. 2011;11(3):1.

31. Siegel S. Statistik Non-Parametrik untuk Ilmu-Ilmu Sosial. Jakarta: PT Gramedia Pustaka Utama; 1997.

32. Madiyono B, Moeslichan S, Sastroasmoro S, Budiman I, Purwanto SH. Perkiraan Besar Sampel. Jakarta: Sagung Seto; 2002.

33. Sugiyono. Metode Penelitian Pendidikan. Bandung: Alfabeta; 2011. 